\title{
Von Willebrand Factor Multimers Measurement
}

National Cancer Institute

\section{Source}

National Cancer Institute. von Willebrand Factor Multimers Measurement. NCI

Thesaurus. Code C147336.

The determination of the amount of von Willebrand factor multimers present in a sample. 